\title{
Antimuscarinic Effects of Antihistamines: Quantitative Evaluation by Receptor-Binding Assay
}

\author{
Nobuo KUBO, Osamu SHIRAKAWA, Takayoshi KUNO and Chikako TANAKA* \\ Department of Pharmacology. Kobe University School of Medicine, Chuo-ku, Kobe 650, Japan
}

Accepted November 22. 1986

\begin{abstract}
Quantitative evaluation of antimuscarinic effects of antihistamines $\left(\mathrm{H}_{1}\right.$ and $\mathrm{H}_{2}$-receptor antagonists) was carried out using a receptor-binding assay. The inhibition constants ( $K_{i}$ values) of twenty seven $H_{1}$-receptor antagonists, one related antidepressant and three $\mathrm{H}_{2}$-receptor antagonists at $\mathrm{H}_{1}$-receptors and muscarinic receptors in the bovine cerebral cortex were determined. All the $\mathrm{H}_{2}$ receptor antagonists examined showed very low affinity for the muscarinic receptors. On the other hand, some $\mathrm{H}_{1}$-receptor antagonists (mequitazine, cyproheptazine, clemastine, diphenylpyraline, promethazine, homochlorcyclizine and alimemazine) had high affinity for the muscarinic receptors $\left(K_{i}=5.0-38 n M\right)$. Another group of $\mathrm{H}_{1}$-receptor antagonists (mepyramine, terfenadine, metapyrilen, azelastine, hydroxyzine and meclizine) had low affinity for the muscarinic receptors $\left(K_{i}=3,600-\right.$ $30,000 \mathrm{nM}$ ). Thus, a broad range of antimuscarinic potencies among the antihistamines was demonstrated. These results should provide helpful information with regard to the clinical and experimental use of antihistamines.
\end{abstract}

Histamine has been shown to stimulate two different types of receptors which are referred to as $\mathrm{H}_{1}$ - and $\mathrm{H}_{2}$-receptors. $\mathrm{H}_{1}$ receptor mediates histamine-induced contraction of smooth muscles of the small intestine and bronchi. $\mathrm{H}_{2}$-receptor mediates the action of histamine in stimulating gastric acid secretion. The receptors are defined pharmacologically from the antagonists which selectively block the response of these tissues to histamine stimulation (1, 2).

Some of the classical $\mathrm{H}_{1}$-receptor antagonists such as diphenhydramine (3) and antazoline (4) were reported to display substantial atropine-like activity which was assessed by a bioassay system. In the following years, numerous antihistamines of much greater potency and specificity either at $\mathrm{H}_{1}$ or $\mathrm{H}_{2}$-receptors were synthesized. While some of these drugs are thought to possess antimuscarinic activities which may cause certain adverse effects in clinical use, quantitative evaluation of the antimuscarinic effects has not been reported. Recently, receptor-

\footnotetext{
* To whom correspondence should be addressed.
}

binding studies have provided a new method for quantitative evaluation of the affinities of some drugs for various receptors (5). In this study, we determined the affinities of a large series of antihistamines for $\mathrm{H}_{1}$ - and muscarinic receptors of bovine cerebral cortex using a receptor-binding assay and showed that there is a broad range of antimuscarinic potencies among the antihistamines.

\section{Materials and Methods}

Membrane preparations: Bovine brains were obtained from a local slaughterhouse, and stored at $-80^{\circ} \mathrm{C}$ until use. Membrane preparations were prepared as described previously (6). Briefly, the cerebral cortex was homogenized in 20 volumes of ice-cold $50 \mathrm{mM}$ Tris- $\mathrm{HCl}(\mathrm{pH} \mathrm{7.4)}$ with a Kinematika Polytron PT-10 (setting 7, $20 \mathrm{sec}$ ). The homogenates were centrifuged three times for $10 \mathrm{~min}$ at $50,000 \times \mathrm{g}$ at $4^{\circ} \mathrm{C}$ with resuspension of the intermediate pellet from each centrifugation in the ice-cold Tris buffer. The final pellets were used immediately or stored at $-80^{\circ} \mathrm{C}$ until assayed.

Radioligand-binding assay: ${ }^{3} \mathrm{H}$-mepyra- 
mine and ${ }^{3} \mathrm{H}$-quinuclidinyl benzilate (QNB) binding assays were performed as described previously (7, 8). Briefly, the membrane preparations were added to siliconized glass test tubes containing ${ }^{3} \mathrm{H}$-mepyramine or ${ }^{3} \mathrm{H}$ QNB and various drugs in the Tris buffer, with a final assay volume of $0.6 \mathrm{ml}$. The assay tubes were incubated for $30 \mathrm{~min}$ at $25^{\circ} \mathrm{C}$ for ${ }^{3} \mathrm{H}$-mepyramine binding and for $60 \mathrm{~min}$ at $25^{\circ} \mathrm{C}$ for ${ }^{3} \mathrm{H}-\mathrm{QNB}$ binding. The incubation was terminated by rapid filtration over polyetylenimine-treated glass fiber filters (9) under vacuum. The filters were then rinsed rapidly with $20 \mathrm{ml}$ of ice-cold Tris buffer. Radioactivity trapped on the filters was counted by liquid scintillation spectroscopy. Nonspecific bindings were determined in the presence of $2 / \mathrm{M}$ triprolidine for ${ }^{3} \mathrm{H}$ mepyramine binding and $1 \mu \mathrm{M}$ atropine for ${ }^{3} \mathrm{H}$-QNB binding. Protein was assayed by the method of Lowry et al. (10).

Materials: ${ }^{3} \mathrm{H}$-mepyramine (24.1 $\mathrm{Ci} / \mathrm{mmol}$ ) and ${ }^{3} \mathrm{H}-\mathrm{QNB}$ (30.1 $\left.\mathrm{Ci} / \mathrm{mmol}\right)$ were obtained from New England Nuclear. Other reagents were purchased from Sigma. Examined compounds were as follows: mepyramine, metapyrilen, tripelennamine, dimenhydrinate and antazoline (Sigma); triprolidine and diphenhydramine (Tanabe Pharmaceutical); promethazine (Shionogi Pharmaceutical); dchlorphenilamine (Shering); doxepin. hydroxyzine and meclizine (Taito-Pfizer); clemastine and ketotifen (Sandoz); homochlorcyclizine. diphenylpyraline and azelastine (Eisai): mequitazine and ranitizine (Shinnippon Jistugyo): cyproheptazine (Merck Sharp \& Dohme); alimemazine (Dai-ichi Pharmaceutical); pyrathiazine (Upjohn); carbinoxamine (Taisho Pharmaceutical); dimethindene (Ciba-Geigy Japan): dipheterol (Toyama Chemical); isothipendyl (Sumitomo Chemical); mebhydroline (Bayer); astemizole (Janssen Pharmaceutical); terfenadine (Dow Chemical); cimetidine (SK\&F Fujisawa): famotidine (Yamanouchi Pharmaceutical).

\section{Results}

${ }^{3} \mathrm{H}$-mepyramine binding: Specific ${ }^{3} \mathrm{H}$ mepyramine binding to the membrane preparations from bovine cerebral cortex was saturable (Fig. 1A). Scatchard plot of specific
${ }^{3} \mathrm{H}$-mepyramine binding was linear and gave a $K_{d}$ value of $1.16 \pm 0.21 \mathrm{nM}$ and a $B_{\max }$ value of $95.4 \pm 5.2 \mathrm{fmol} / \mathrm{mg}$ protein (Fig. 1A). These values are in good agreement with data in the literature $(11,12)$. As shown in Fig. $2 A$, the affinities of various $H_{1}$-receptor antagonists and other drugs for the $\mathrm{H}_{1}$ receptor in the bovine cerebral cortex were determined according to the inhibition of ${ }^{3} \mathrm{H}$ mepyramine binding. The inhibition constants
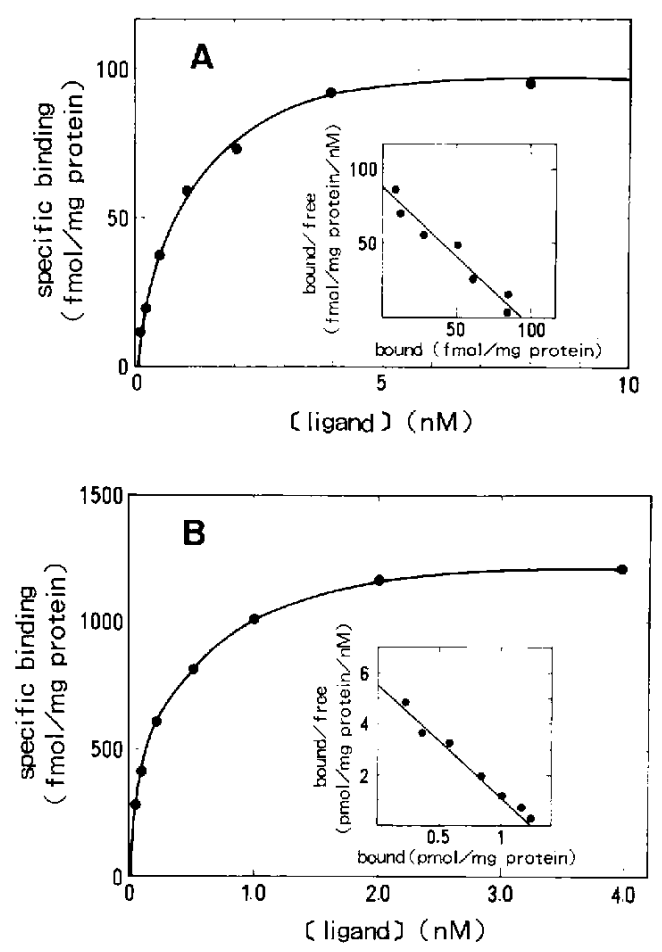

Fig. 1. Characterization of histamine $\mathrm{H}_{1}$ - and muscarinic receptors in bovine cerebral cortex. A) Saturation of ${ }^{3} \mathrm{H}$-mepyramine binding in bovine cerebral cortex. ${ }^{3} \mathrm{H}$-mepyramine binding was measured as described in "Materials and Methods" using various concentrations of ${ }^{3} \mathrm{H}$-mepyramine in the presence (for nonspecific binding) and absence (for total binding) of $2 \mu \mathrm{M}$ triprolidine. Specific binding was the difference between total and nonspecific binding. The experiment was repeated three times with similar results. Inset: Scatchard plot. B) Saturation of ${ }^{3} \mathrm{H}$-ONB binding in bovine cerebral cortex. ${ }^{3} \mathrm{H}-\mathrm{ONB}$ binding was performed using various concentrations of ${ }^{3} \mathrm{H}-\mathrm{ONB}$ in the presence and absence of $1 \not \mu \mathrm{M}$ atropine. The experiment was replicated three times with similar results. Inset: Scatchard plot. 

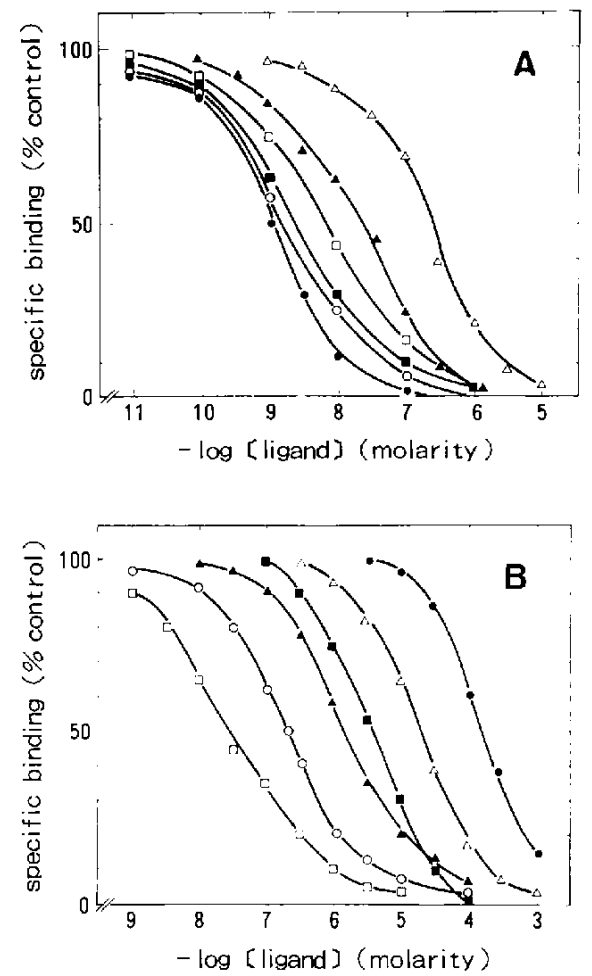

Fig. 2. Competition by antihistamines for ${ }^{3} \mathrm{H}$ mepyramine (A) and ${ }^{3} \mathrm{H}-\mathrm{ONB}$ (B) binding to the membrane preparations from bovine cerebral cortex. The concentration of ${ }^{3} \mathrm{H}$-mepyramine and ${ }^{3} \mathrm{H}-\mathrm{ONB}$ were $1 \mathrm{nM}$ and the concentrations of unlabelled compounds were varied as indicated. (O) mepyramine, (O) diphenylpyraline, ( $\square$ ) triprolidine, ( $\square$ ) mequitazine, $(\boldsymbol{\Delta})$ diphenhydramine, $(\triangle)$ antazoline. The experiment was repeated three times with similar results.

$\left(K_{i}\right)$ were calculated from the equation $K_{i}=\mid C 50 /\left(1+C / K_{i}\right)$, where $1 C 50=$ concentration causing $50 \%$ inhibition of specific binding which was obtained from the displacement experiments, $\mathrm{C}={ }^{3} \mathrm{H}$-ligand concentration used in the displacement experiment, and $K_{\mathrm{d}}=$ dissociation constant from the Scatchard analysis of the equilibrium experiments. Calculated $\mathrm{K}_{\mathrm{i}}$ values of $\mathrm{H}_{1}$-receptor antagonists for ${ }^{3} \mathrm{H}$-mepyramine binding were in the range of $0.24 \mathrm{nM}$ (mepyramine) to 160 nM (antazoline, dipheterol) (Table 1). Doxepin, an antidepressant, exhibited the most potent $\mathrm{H}_{7}$-receptor antagonism, and all the three $\mathrm{H}_{2}$-receptor antagonists examined showed very low affinities for the $\mathrm{H}_{1}$-receptor (Fig. 2.A and Table 1).

${ }^{3} \mathrm{H}-\mathrm{QNB}$ binding: Specific ${ }^{3} \mathrm{H}$-ONB binding to the membrane preparations from bovine cerebral cortex was also saturable. and the Scatchard analysis gave a $K_{a}$ value of $0.24 \pm 0.02 \mathrm{nM}$ and $a B_{\max }$ value of $1240 \pm 270$ $\mathrm{fmol} / \mathrm{mg}$ protein (Fig. 1B). These values are in agreement with data in the literature (13, 14). The Scatchard plot of specific ${ }^{3} \mathrm{H}-\mathrm{QNB}$ binding was linear, thereby indicating a single class of high affinity binding sites in the bovine cerebral cortex (Fig. 1B). As shown in Fig. 2B and Table 1, a group of $\mathrm{H}_{1}$ receptor antagonists (mequitazine, cyproheptazine, clemastine, diphenylpyraline, promethazine, homochlorcyclizine and alimemazine) showed a potent antagonism for the muscarinic receptor $\left(K_{i}=5.0-38 \mathrm{nM}\right)$. Another group of $\mathrm{H}_{1}$-receptor antagonists (mepyramine, terfenadine, metapyrilen, azelastine, hydroxyzine and meclizine) exhibited a weak antagonism of the muscarinic receptor $\left(K_{i}=3,600-30,000 n M\right)$. Other $\mathrm{H}_{1}$ antagonists showed moderate affinity for the muscarinic receptors. Doxepin also showed high affinity for the muscarinic receptor, and three $\mathrm{H}_{2}$-antagonists had little cross-reactivity (Table 1). Hill coefficients for all antihistamines studied were essentially equal to unity (Table 1), suggesting the antagonistic nature of these compounds for muscarinic receptors (15).

The ratio of the $\mathrm{K}_{\mathrm{i}}$ value with ${ }^{3} \mathrm{H}$ mepyramine binding to that with ${ }^{3} \mathrm{H}-\mathrm{QNB}$ binding for each drug was calculated in order to quantitatively evaluate the selectivity (Table 1). Except for several drugs (mepyramine, metapyrilen, ketotifen, dimethindene, azelastine and hydroxyzine, $\mathrm{K}_{\mathbf{i}}$ value ratio= 590-130,000), most $H_{1}$-receptor antagonists seemed to have substantial interaction with the muscarinic receptors. That is, thirteen compounds out of twenty-seven $\mathrm{H}_{1}$ antagonists had a ratio of less than 100 . indicating considerably low selectivity. For example. mequitazine showed almost equal affinities for the $\mathrm{H}_{1}$ - and the muscarinic receptors $\left(K_{i}\right.$ value ratio $\left.=1.1\right)$.

\section{Discussion}

This paper presents the data of the binding 
Table 1. Inhibition constants of antihistamines and related compounds for histamine $\mathrm{H}_{1}$-receptors and muscarinic acetylcholine receptors in bovine cerebral cortex

\begin{tabular}{|c|c|c|c|c|c|}
\hline \multirow{3}{*}{$\bar{H}_{1}$-antagonists } & \multicolumn{3}{|c|}{$\begin{array}{c}\text { Inhibition of } \\
{ }^{3} \mathrm{H} \text {-QNB } \\
\text { binding }\end{array}$} & \multirow{3}{*}{$\begin{array}{c}\text { Inhibition of } \\
{ }^{3} \mathrm{H} \text {-mepyramine } \\
\text { binding } \\
\left(K_{\text {ib, nM }}\right)\end{array}$} & \multirow[t]{2}{*}{$\begin{array}{l}K_{i} \text { value } \\
\text { ratio } \\
\left(K_{i a} / K_{i b}\right)\end{array}$} \\
\hline & \multicolumn{2}{|c|}{$\left(K_{i a}, n M\right)$} & \multirow[t]{2}{*}{$(\mathrm{nH})$} & & \\
\hline & & & & & \\
\hline Mequitazine & \multicolumn{2}{|c|}{$5.0 \pm 0.2$} & $0.90 \pm 0.06$ & \multirow{2}{*}{$\begin{array}{ll}4.4 & \pm 0.6 \\
2.6 & \pm 0.2\end{array}$} & 1.1 \\
\hline Cyproheptazine & \multicolumn{2}{|c|}{$8.8 \pm 0.4$} & $0.92 \pm 0.04$ & & 3.4 \\
\hline Ciemastine & 16 & \pm 2 & $0.97 \pm 0.06$ & $0.26 \pm 0.03$ & 62 \\
\hline Diphenvlpyraline & 20 & \pm 2 & $0.92 \pm 0.05$ & $0.84 \pm 0.09$ & 24 \\
\hline Promethazine & 22 & \pm 2 & $0.82 \pm 0.05$ & $2.6 \pm 0.2$ & 8.5 \\
\hline Homochlorcyclizine & 26 & \pm 2 & $0.96 \pm 0.03$ & $1.8 \pm 0.1$ & 14 \\
\hline Alimemazine & 38 & \pm 3 & $0.95 \pm 0.04$ & $0.72 \pm 0.10$ & 53 \\
\hline Isothipendyl & 74 & \pm 8 & $0.92 \pm 0.05$ & $0.42 \pm 0.04$ & 180 \\
\hline Dimenhydrinate & 160 & \pm 10 & $0.93 \pm 0.07$ & $8.4 \pm 0.4$ & 19 \\
\hline Mebhydroline & 180 & \pm 20 & $0.88 \pm 0.10$ & $7.6 \pm 0.6$ & 24 \\
\hline Pyrathiazine & 220 & \pm 10 & $0.89 \pm 0.04$ & $1.3 \pm 0.2$ & 170 \\
\hline Ketotifen & 260 & \pm 20 & $0.94=0.04$ & $0.32 \pm 0.04$ & 810 \\
\hline Diphenhydramine & 280 & \pm 50 & $1.0 \pm 0.1$ & $14 \pm 2$ & 20 \\
\hline d-Chlorpheniramine & 300 & \pm 20 & $0.96 \pm 0.06$ & $2.6 \pm 0.3$ & 120 \\
\hline Dimethindene & 320 & \pm 40 & $0.92 \pm 0.03$ & $0.46 \pm 0.04$ & 700 \\
\hline Triprolidine & 500 & \pm 50 & $0.95 \pm 0.06$ & $2.2 \pm 0.4$ & 230 \\
\hline Carbinoxamine & 740 & \pm 40 & $0.97 \pm 0.12$ & $3.4 \pm 0.4$ & 220 \\
\hline Tripelen namine & 1300 & \pm 200 & $0.92 \pm 0.05$ & $7.4 \pm 0.6$ & 180 \\
\hline Astemizole & 2400 & \pm 300 & $0.94 \pm 0.08$ & $8.0 \pm 1.1$ & 300 \\
\hline Dipheterol & 3000 & \pm 400 & $0.87 \pm 0.09$ & $160 \pm 10$ & 19 \\
\hline Antazoline & 3000 & \pm 400 & $0.82 \pm 0.09$ & $160 \pm 10$ & 19 \\
\hline Meclizine & 3600 & \pm 120 & $0.98 \pm 0.04$ & $140 \pm 10$ & 26 \\
\hline Hydroxyzine & 3800 & \pm 100 & $0.90 \pm 0.09$ & $6.4 \pm 1.0$ & 590 \\
\hline Azelastine & 4200 & \pm 500 & $1.1 \pm 0.1$ & $6.4 \pm 0.7$ & 660 \\
\hline Metapyrilen & 5000 & \pm 300 & $1.0 \pm 0.1$ & $2.8 \pm 0.5$ & 1800 \\
\hline Terfenadine & 12000 & \pm 1000 & $0.97 \pm 0.10$ & $52 \pm 8$ & 230 \\
\hline Mepyramine & 30000 & \pm 2000 & $0.99 \pm 0.04$ & $0.24 \pm 0.03$ & 130000 \\
\hline $\begin{array}{l}\text { Antidepressant } \\
\text { Doxepin }\end{array}$ & 40 & \pm 2 & $0.96 \pm 0.03$ & $0.12 \pm 0.02$ & 330 \\
\hline $\mathrm{H}_{2}$-antagonists & & & & & \\
\hline Famotidine & 28000 & \pm 1000 & $0.92 \pm 0.10$ & $4000 \pm 200$ & 7 \\
\hline Cimetidine & 72000 & \pm 560 & $1.0 \pm 0.1$ & $26000 \pm 800$ & 2.8 \\
\hline Ranitidine & 120000 & \pm 10000 & $1.0 \pm 0.1$ & $90000 \pm 5000$ & 1.3 \\
\hline
\end{tabular}

The inhibition of specific binding of ${ }^{3} \mathrm{H}$-mepyramine $(1 \mathrm{nM})$ and ${ }^{3} \mathrm{H}-\mathrm{ONB}(1 \mathrm{nM})$ binding was determined with seven to ten concentrations of competing drugs assayed in triplicate as shown in Fig. 2 . The mean inhibitory concentration ( 1 C50) values were determined from the log-probit analysis, and $K_{i}$ values were calculated from the equation described in "Results". The Hill coefficient ( $\mathrm{nH}$ ) was calculated as described by Bennett and Yamamura (15). Values are the means \pm S.E. from three independent experiments.

potencies of a large series of antihistamines at the muscarinic acetylcholine receptor and shows that there is a broad range of antimuscarinic potencies $\left(K_{1}=5.0-30.000 \mathrm{nM}\right)$ among the antihistamines. Except for several drugs, many classical and new antihistamines were shown to have antimuscarinic effects. However, the antimuscarinic and antihistaminic potencies for the twenty-seven $\mathrm{H}_{1}$ receptor antagonists studied were not significantly correlated $(r=0.65)$, indicating that the structural requirement for the anti- 
muscarinic effect is different from that for the antihistaminic effect. In general, ethanolamines (prototype: diphenhydramine) and phenotiazines (prototype: promethazine) were potent $\mathrm{H}_{1}$-receptor antagonists that possess significant antimuscarinic activity. On the other hand, ethylenediamines (prototype: mepyramine), alkylamines (prototype: chlorpheniramine) and piperazine (prototype: hydroxyzine) were selective $\mathrm{H}_{1}$-antagonists with no considerable antimuscarinic activity. Seventeen out of twenty-seven $\mathrm{H}_{1}$-receptor antagonists have $K_{i}$ values for muscarinic receptors in the nanomolar range (5.0-740 $n M)$; and in spite of its high $K_{i}$ value $(3,000$ $n M)$, antazoline was reported to have an atropine-like effect (4), probably due to its low selectivity for the $H_{1}$-receptor $\left(K_{i}\right.$ value ratio $=19$ ). Consequently. compounds at the top of the lists (Table 1) will likely block muscarinic receptors at the blood concentrations achieved in clinical practice. Some $\mathrm{H}_{1}$-receptor antagonists with potent antimuscarinic activity are clinicaliy used to combat motion sickness. These include ethanolamines (dimenhydrinate and diphenhydramine) and piperazines (meclizine and others). Since scopolamine was reported to be a potent drug for the prophylaxis and treatment of motion sickness (16), the antimotion sickness activity of some of the $\mathrm{H}_{1}$ receptor antagonists seems to be related to their antimuscarinic ability. As the histamine $\mathrm{H}_{1}$-receptor blockade is suggested to be associated with the sedative activity (17), use of a drug which has both antimuscarinic and antihistaminic effects may be more effective in the treatment of motion sickness. The ranking of these drugs (Table 1) as antmuscarinic agents also can be used clinically to predict the likelihood that these drugs will cause certain adverse effects in patients such as dry mouth, blurred vision, urinary retention and constipation.

Thus, these results will provide helpful information with regard to the clinical and experimental use of antihistamines.

Acknowledgements: This work was supported by grants from the Ministry of Education. Science and Culture and the Ministry of Health and Welfare. Japan. We thank $M$. Ohara for critical reading of the manuscript.

\section{References}

1 Ash, A.S.F. and Schild, H.Q.: Receptors mediating some actions of histamine. Br. J. Pharmacol. 27, 427-439 (1966)

2 Black, J.W.. Duncan, W.A.M., Durant, C.J., Ganallin, C.R. and Parsons, E.M.: Definition and antagonism of histamine $\mathrm{H}_{2}$-receptors. Nature 236, 385-390 (1972)

3 Rekker, R.F., Timmerman, H., Harms, A.F. and Nauta, W.T.: The antihistaminic and anticholinergic activities of optically active diphenhydramine derivatives. Arzneimittelforsch. 21. 688-691 (1971)

4 von Schlichtegroll, A.: Zur Pharmakologie verschiedener Thiophenylpyridylamin-Derivate. Arzneimittelforsch. 7, 237-252 (1957)

5 El-Fakahany, E. and Richelson, E.: Antagonism by antidepressants of muscarinic acetylcholine receptors of human brain. Br. J. Pharmaco!. 78, 97-102 (1983)

6 Kuno, T., Saijoh, K. and Tanaka, C.: Solubilization of $D_{2}$ dopamine receptor coupled to guanine nucleotide regulatory protein from bovine striatum. J. Neurochem. 41,841-847 (1983)

7 Kuno, T., Kubo, N. and Tanaka, C.: Molecular size of histamine $\mathrm{H}-1$ receptor determined by target size analysis. Biochem. Biophys. Res. Commun. 129, 639-644 (1985)

8 Kuno, T., Shirakawa, O. and Tanaka, C.: Regulation of the solubilized bovine cerebral cortex muscarinic receptor by GTP and $\mathrm{Na}^{+}$. Biochem. Biophys. Res. Commun. 112, 948-953 (1983)

9 Bruns, R.F., Lawson-Wendling, K. and Pugsley, T.A.: A rapid filtration assay for soluble receptor using polyethylenimine-treated filters. Anal. Biochem. 132, 74-81 (1983)

10 Lowry, O.H., Rosebrough, N.J., Farr, A.L. and Randall, R.J.: Protein measurement with the Folin phenol reagent. J. Biol. Chem. 193, 265275 (1951)

11 Tran, V.T., Chang, R.S.L. and Snyder, S.H.: Histamine $H$, receptors identified in mammalian brain membranes with $\left[{ }^{3} \mathrm{H}\right]$ mepyramine. Proc. Natl. Acad. Sci. U.S.A. 75, 6290-6294 (1978)

12 Chang, R.S.L., Tran, V.T. and Snyder, S.H.: Characteristics of histamine $\mathrm{H}_{1}$ - receptors in peripheral tissues labeled with $\left[{ }^{3} \mathrm{H}\right]$ mepyramine. J. Pharmacol. Exp. Ther. 209, 437-442 (1979)

13 Yamamura, H.I. and Snyder, S.H.: Muscarinic cholinergic binding in rat brain. Proc. Natl. Acad. Sci. U.S.A. 71, 1725-1729 (1974)

14 Shirakawa, 0 . and Tanaka, C.: Molecular characterization of muscarinic receptor subtypes in bovine cerebral cortex by radiation inactivation and molecular exclusion H.P.L.C. Br. J. Phar- 
macol. 86, 375-383 (1985)

15 Bennett, J.P. and Yamamura, H.I.: Neurotransmitter, hormone, or drug receptor binding methods. In Neurotransmitter Receptor Binding. Edited by Yamamura. H.I., Enna, S.J. and Kuhar. M.J., p. 61-89, Raven Press, New York (1985)

16 Brand, J.J. and Perry, W.L.M.: Drugs used in motion sickness. Pharmacol. Rev. 18, 895-924 (1966)

17 Richelson, E. and Nelson, A.: Antagonism by neuroleptics of neurotransmitter receptors of normal human brain in vitro. Eur. J. Pharmacol. 103, 197-204 (1984) 